University of New Hampshire

University of New Hampshire Scholars' Repository

$10-2002$

\title{
Children Abducted by Family Members: National Estimates and Characteristics.
}

\author{
Heather Hammer \\ Temple University \\ David Finkelhor \\ University of New Hampshire - Main Campus, David.Finkelhor@unh.edu \\ Andrea J. Sedlack \\ Westat, Inc.
}

Follow this and additional works at: https://scholars.unh.edu/ccrc

Part of the Criminology Commons

\section{Recommended Citation}

Hammer, Heather; Finkelhor, David and Sedlack, Andrea J. Children abducted by family members: National estimates and characteristics. Juvenile Justice Bulletin - NCJ196466, (pgs. 1-12). Washington, DC: US Government Printing Office.

This Article is brought to you for free and open access by the Research Institutes, Centers and Programs at University of New Hampshire Scholars' Repository. It has been accepted for inclusion in Crimes Against Children Research Center by an authorized administrator of University of New Hampshire Scholars' Repository. For more information, please contact Scholarly.Communication@unh.edu. 
J. Robert Flores

OJJDP Administrator

\section{Children Abducted by Family Members: National Estimates and Characteristics}

\author{
Heather Hammer, David Finkelhor, and \\ Andrea J. Sedlak
}

The words "missing child" call to mind tragic and frightening kidnappings reported in the national news. But a child can be missing for many reasons, and the problem of missing children is far more complex than the headlines suggest. Getting a clear picture of how many children become missing — and why —is an important step in addressing the problem. This series of Bulletins provides that clear picture by summarizing findings from the Second National Incidence Studies of Missing, Abducted, Runaway, and Thrownaway Children (NISMART-2). The series offers national estimates of missing children based on surveys of households, juvenile residential facilities, and law enforcement agencies. It also presents statistical profiles of these children, including their demographic characteristics and the circumstances of their disappearance.

This Bulletin presents results from the initial analysis of family abduction data collected by the Second National Incidence Studies of Missing, Abducted, Runaway, and Thrownaway Children (NISMART-2), National Household Surveys of Adult Caretakers and Youth. These surveys were conducted during 1999 and reflect a 12 -month period. Because the vast majority of cases were concentrated in 1999, the annual period referred to in the Bulletin is 1999 . 


\section{Defining Family Abduction}

For the purposes of NISMART-2, family abduction was defined as the taking or keeping of a child by a family member in violation of a custody order, a decree, or other legitimate custodial rights, where the taking or keeping involved some element of concealment, flight, or intent to deprive a lawful custodian indefinitely of custodial privileges.

Some of the specific definitional elements are as follows:

- Taking: Child was taken by a family member in violation of a custody order or decree or other legitimate custodial right.

- Keeping: Child was not returned or given over by a family member in violation of a custody order or decree or other legitimate custodial right.

- Concealment: Family member attempted to conceal the taking or whereabouts of the child with the intent to prevent return, contact, or visitation.

- Flight: Family member transported or had the intent to transport the child from the State for the purpose of making recovery more difficult.

- Intent to deprive indefinitely: Family member indicated an intent to prevent contact with the child on an indefinite basis or to affect custodial privileges indefinitely.

- Child: Person under 18 years of age. For a child 15 or older, there needed to be evidence that the family member used some kind of force or threat to take or to detain the child, unless the child was mentally disabled.

- Family member: A biological, adoptive, or foster family member; someone acting on behalf of such a family member; or the romantic partner of a family member.

\section{Key Findings}

Family abduction is a type of crime and child welfare problem for which only limited statistical information has been available. Among the key findings from this Bulletin are the following:

An estimated 203,900 children were victims of a family abduction in 1999. Among these, 117,200 were missing from their caretakers, and, of these, an estimated 56,500 were reported to authorities for assistance in locating the children.

Forty-three percent of the children who were victims of family abduction were not considered missing by their caretakers because the caretakers knew the children's whereabouts or were not alarmed by the circumstances (see "Conceptualizing the Problem," below).

- Forty-four percent of family abducted children were younger than age 6 .

- Fifty-three percent of family abducted children were abducted by their biological father, and 25 percent were abducted by their biological mother.

Forty-six percent of family abducted children were gone less than 1 week, and 21 percent were gone 1 month or more.

- Only 6 percent of children abducted by a family member had not yet returned at the time of the survey interview.

\section{Conceptualizing the Problem}

Family abducted children are typically thought of as simply one subcategory of missing children; yet, in reality, family abductions are part of a larger problem. It is possible for a child to have been unlawfully removed from custody by a family member, but for that child's whereabouts to be fully known. Thus, a child can be abducted, but not necessarily missing. (See sidebar on defining family abduction.) An example would be a situation in which a child is abducted by a noncustodial father and taken to the father's home in a different State, at an address well known to the custodial mother, and the father simply refuses to return the child.

NISMART-2 estimated the number of children who were abducted by a family member in the course of a year; the number of such children who were missing to their caretakers ("caretaker missing"), in that the child's whereabouts were unknown, causing the caretaker to be alarmed for at least an hour and to look for the child; and the number of family abducted children who were "reported missing," meaning that the caretaker contacted the police or a missing children's agency to help locate a child whose whereabouts were unknown.

In considering the estimates of family abducted children, several issues should be kept in mind. First, the Household Survey respondents were predominantly female caretakers of children. Second, it was generally the aggrieved caretaker who provided all of the information about custodial rights and privileges and other elements 
of the episode used to decide whether an episode qualified as a family abduction. In family abductions, these elements typically are a matter of dispute between the parties involved. NISMART researchers did not attempt to verify respondent statements.

\section{Methodology}

The family abduction estimates are based on the NISMART-2 National Household Surveys of Adult Caretakers and Youth. The surveys were conducted during 1999, using computer-assisted telephone interviewing methodology to collect information from a national probability sample of households. A total of 16,111 interviews were completed with an adult primary caretaker, resulting in an 80-percent cooperation rate among eligible households with children, and a 61-percent response rate. The total number of children identified by adult caretakers in the Household Survey sample was 31,787. Each primary caretaker who completed an interview was asked for permission to interview one randomly selected youth in the household between the ages of 10 and 18. Permission was obtained for 60 percent of the selected youth, yielding 5,015 youth interviews and a 95-percent response rate among the youth for whom permission to interview was granted. Both youth and adult interview data were weighted to reflect the Census-based population of children.
The Household Surveys were designed to screen for potentially countable NISMART-2 episodes, to collect demographic information about the household and its members, to conduct indepth followup interviews specific to each type of episode being studied, and to collect information about any actual or attempted sexual assaults that may have occurred during an episode. The types of episodes studied were family abductions, nonfamily abductions, runaway/thrownaway episodes, and missing child episodes that involved a child being lost or injured or missing due to a benign explanation (e.g., a miscommunication between parent and child).

Respondents were screened with a set of 17 questions to determine their eligibility for an indepth followup interview pertaining to each type of missing child episode. Table 1 presents the five adult screening questions that led to a family abduction followup interview; the youth screening questions were essentially identical.

The family abduction estimates reported in this Bulletin are unified estimates that combine the countable family abductions described by adult caretakers and youth in the Household Surveys. ${ }^{1}$ Any individual child is counted only once, even if an abduction was reported for the same child in both the adult and youth interviews. For details about the unification, weighting procedures, and variance estimation, see OJJDP's forthcoming NISMART-2 Household Survey Methodology Technical Report.

\section{Table 1: Household Survey Family Abduction Screening Questions}

- Was there any time when anyone tried to take [this child/any of these children] away from you against your wishes?

In the past 12 months, did any family member outside your household, such as a spouse, an ex-spouse, an ex-partner, brother, sister, parent, in-law, or any other person you consider a family member or someone acting for them, do any of the following things:

- Did any family member or someone acting for them take or try to take [this child/any of these children] in violation of a custody order, an agreement, or other child living arrangement?

- Did any family member outside of your household keep or try to keep [this child/any of these children] from you when you were supposed to have [him/her/them] even if for just a day or weekend?

- Did any family member conceal [this child/any of these children] or try to prevent you from having contact with [him/her/them]?

- Has anyone ever kidnapped or tried to kidnap [this child/any of these children]?

\section{Results}

Table 2 shows that the total number of children who were abducted by a family member in 1999 is estimated to be 203,900 . Of these, the number counted as "caretaker missing" (i.e., the caretaker did not know where the child was, became alarmed for at least an hour, and looked for the child) is estimated to be 117,200 (about 57 percent of all children who experienced a family abduction), and the number "reported 
Table 2: Estimates of Family Abducted Children

\begin{tabular}{lcc} 
Category & $\begin{array}{c}\text { Estimated Number } \\
\text { (95\% Confidence Interval) }\end{array}$ & Percent \\
\hline All family abductions & 203,900 & 100 \\
Caretaker missing $^{\dagger}$ & $(151,700-256,100)$ & 57 \\
Reported missing $^{\ddagger}$ & 117,200 & 28 \\
& $(79,000-155,400)$ & \\
\hline
\end{tabular}

Note: All estimates are rounded to the nearest 100.

* The 95-percent confidence interval indicates that if the study were repeated 100 times, 95 of the replications would produce estimates within the ranges noted

† Whereabouts unknown to caretaker, caretaker alarmed and tried to locate child. Includes reported missing cases.

‡ Reported to police or a missing children's agency for purposes of locating the child. This is a subset of caretaker missing cases.

\section{Characteristics of Family Abducted Children}

Table 3 indicates that, although children of any age can be victims of family abduction, younger children appear to be particularly vulnerable. In 1999, 44 percent of family abducted children were younger than age 6 . Older teenagers (ages 15-17) accounted for a small proportion of family abduction victims; this finding may reflect the relative independence of teenagers, which makes it more difficult for parents to control where they go and stay. Boys and girls were equally likely to experience family abductions.

missing" (i.e., reported to police or a missing children's agency for purposes of being located) is estimated to be 56,500 ( 28 percent of all children who experienced a family abduction). The diagram on this page illustrates the proportional relationships between all family abducted children and the subsets of children who were caretaker missing and reported missing. It also shows that the children who were reported missing are a subset of those who were caretaker missing. (Note that this Bulletin presents data on the characteristics of all family abducted children, not just those who were classified as caretaker missing or reported missing.)

\section{Estimates of Family Abducted Children}

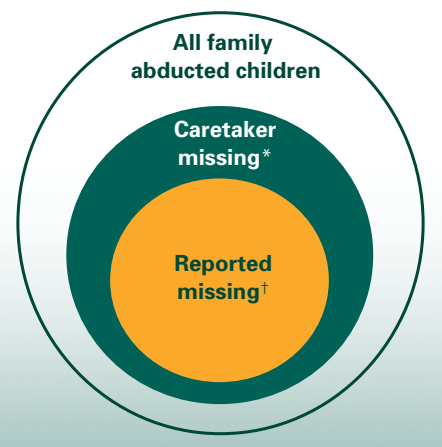

* Whereabouts unknown to caretaker, caretaker alarmed and tried to locate child.

† Reported to police or a missing children's agency for purposes of locating the child.
The racial/ethnic distribution of family abducted children corresponds to the distribution of children in the general population. This indicates that family abductions do not occur disproportionately in any one racial/ethnic group.

Not surprisingly, family abductions were much more likely to occur in families where children were not living with both parents-the circumstance that gives rise to motives for family abduction. Forty-two percent of the family abducted children were living with one parent, and another 17 percent were living with one parent and that parent's partner. Fifteen percent of children abducted by family members were abducted from relatives or foster parents.

\section{Characteristics of Familly Abduction Perpetrators}

As shown in table 4, a little more than one-third 35 percent) of family abducted children were abducted by multiple offenders (e.g., a father and his girlfriend). The following discussion of perpetrator characteristics refers to the perpetrator most closely related to the abducted child.

Table 5 shows that just more than half (53 percent) of children abducted by a family member in 1999 were abducted by the biological father. Twenty-five percent were abducted by the biological mother. Fourteen percent were abducted by a grandparent, and there were also some abductions by a sibling, uncle, aunt, and 


\begin{tabular}{|c|c|c|c|c|c|}
\hline $\begin{array}{l}\text { Child } \\
\text { Characteristic }\end{array}$ & $\begin{array}{l}\text { Estimated } \\
\text { Number }\end{array}$ & $\begin{array}{c}95 \% \text { Confidence } \\
\text { Interval* }\end{array}$ & $\begin{array}{c}\text { Percent } \\
(n=203,900)\end{array}$ & $\begin{array}{c}95 \% \text { Confidence } \\
\text { Interval* }\end{array}$ & $\begin{array}{c}\text { Percent of } \\
\text { U.S. Child } \\
\text { Population }^{\dagger} \\
(N=70,172,700)\end{array}$ \\
\hline \multicolumn{6}{|l|}{ Age } \\
\hline $0-2$ & 43,400 & $(11,000-75,700)$ & 21 & $(7-35)$ & 16 \\
\hline $3-5$ & 47,100 & $(22,800-71,400)$ & 23 & $(13-34)$ & 16 \\
\hline $6-11$ & 71,000 & $(42,100-100,000)$ & 35 & $(23-46)$ & 34 \\
\hline $12-14$ & 35,200 & $(14,900-55,500)$ & 17 & $(8-26)$ & 17 \\
\hline $15-17$ & $7,200^{\ddagger}$ & $(<100-15,400)$ & $4^{\ddagger}$ & $(<1-8)$ & 17 \\
\hline \multicolumn{6}{|l|}{ Gender } \\
\hline Male & 100,300 & $(60,500-140,100)$ & 49 & $(36-62)$ & 51 \\
\hline Female & 103,500 & $(69,700-137,400)$ & 51 & $(38-64)$ & 49 \\
\hline \multicolumn{6}{|l|}{ Race/ethnicity } \\
\hline White, non-Hispanic & 119,400 & $(78,100-160,600)$ & 59 & $(44-73)$ & 65 \\
\hline Black, non-Hispanic & $23,900^{\ddagger}$ & $(8,200-39,600)$ & $12^{\ddagger}$ & $(4-19)$ & 15 \\
\hline Hispanic & 40,600 & $(7,900-73,300)$ & 20 & $(5-34)$ & 16 \\
\hline Other & 16,200 & $(3,400-29,000)$ & 8 & $(2-14)$ & 5 \\
\hline No information & $3,800^{\ddagger}$ & $(<100-11,200)$ & $2^{\ddagger}$ & $(<1-12)$ & - \\
\hline \multicolumn{6}{|l|}{ Family structure } \\
\hline Two parents & $7,200^{\ddagger}$ & $(<100-15,700)$ & $4^{\ddagger}$ & $(<1-8)$ & - \\
\hline Single parent & 85,500 & $(51,400-119,600)$ & 42 & $(26-58)$ & - \\
\hline One parent and partner & 35,300 & $(15,700-54,900)$ & 17 & $(7-27)$ & - \\
\hline $\begin{array}{l}\text { One parent, partner } \\
\text { unknown }\end{array}$ & $800^{\ddagger}$ & $(<100-2,500)$ & $<1^{\ddagger}$ & $(<1-1)$ & - \\
\hline Relative or foster parent & 30,300 & $(<100-62,100)$ & 15 & $(1-29)$ & - \\
\hline No parent & $3,700^{\ddagger}$ & $(<100-8,700)$ & $2^{\ddagger}$ & $(<1-4)$ & - \\
\hline No information & 41,000 & $(12,300-69,700)$ & 20 & $(8-32)$ & - \\
\hline
\end{tabular}

Note: All estimates are rounded to the nearest 100. Percents may not sum to 100 because of rounding.

* The 95-percent confidence interval indicates that if the study were repeated 100 times, 95 of the replications would produce estimates within the ranges noted.

† Age, gender, and race for the U.S. population were based on the average monthly estimates of the population ages 0-17 for 1999 (U.S. Census Bureau, 2000).

‡ Estimate is based on too few sample cases to be reliable.

mother's boyfriend. ${ }^{2}$ Given the likelihood of being abducted by the biological father, it is not surprising that 66 percent of the family abducted children were abducted by a male. The age distribution in table 5 shows that 45 percent of the family abducted children were abducted by perpetrators in their 30 s.

\section{Characteristics of Family Abduction Episodes}

Location and season. Table 6 shows that children abducted by a family member usually were in their own home or yard (36 percent) or in someone else's home or yard (37 percent) just prior to the abduction. Removal from school or daycare was relatively infrequent $(7$ percent). Sixty-three percent of children abducted by a family 
Table 4: Multiple Perpetrators in Family Abductions

\begin{tabular}{lcc} 
& $\begin{array}{c}\text { Estimated Number } \\
\text { of Family } \\
\text { Abducted Children }\end{array}$ & $\begin{array}{c}\text { Percent } \\
(\boldsymbol{n}=\mathbf{2 0 3 , 9 0 0 )}\end{array}$ \\
\hline $\begin{array}{l}\text { More than one } \\
\text { perpetrator }\end{array}$ & & \\
Yes & 72,400 & 35 \\
No & 123,500 & 61 \\
No information & $8,000^{*}$ & $4^{*}$ \\
Number of perpetrators & & \\
One & 123,500 & 61 \\
Two & 59,800 & 29 \\
Three & $7,200^{*}$ & $4^{*}$ \\
Four or more & $5,400^{*}$ & $3^{*}$ \\
No information & $8,000^{*}$ & $4^{*}$ \\
\hline
\end{tabular}

Note: All estimates are rounded to the nearest 100. Percents may not sum to 100 because of rounding.

* Estimate is based on too few sample cases to be reliable.

member were with the abductor, under lawful circumstances, immediately prior to the abduction. Some seasonal variation in family abductions is evident. Thirty-five percent of children were abducted in the summer (June through August), probably because children tend to spend time with noncustodial parents in the summer, thus increasing opportunities for abduction.

Duration. Table 6 also shows that the vast majority of children abducted by a family member had been returned at the time of the interview (91 percent). Forty-six percent of all family abducted children were gone less than 1 week, and 23 percent were gone less than 1 day. The proportion gone for 1 month or longer was 21 percent, and 6 percent were gone for 6 months or longer. Only 6 percent had not yet returned at the time of the survey interview; all of these children had, however, been located. ${ }^{3}$ (Seventy-eight percent of the children who had not returned had been gone 6 months or more; the remaining 22 percent had been gone at least 1 month but less than 6 months. These figures are not shown in the table.)
Table 5: Characteristics of Family Abduction Perpetrators

\begin{tabular}{|c|c|c|}
\hline $\begin{array}{l}\text { Perpetrator } \\
\text { Characteristic }\end{array}$ & $\begin{array}{l}\text { nated Number } \\
\text { of Family } \\
\text { ucted Children }\end{array}$ & $\begin{array}{c}\text { Percent } \\
(n=203,900)\end{array}$ \\
\hline \multicolumn{3}{|l|}{ Relationship to child } \\
\hline Child's father & 108,700 & 53 \\
\hline Child's mother & 50,500 & 25 \\
\hline Child's stepfather & $3,300 *$ & $2 *$ \\
\hline Child's sister & $1,900 *$ & $1 *$ \\
\hline Child's uncle & $6,000 *$ & $3 *$ \\
\hline Child's aunt & $3,000 *$ & $1 *$ \\
\hline Child's grandfather & $13,700^{*}$ & $7 *$ \\
\hline Child's grandmother & $13,400 *$ & $7 *$ \\
\hline Child's mother's boyfriend & $3,200 *$ & $2^{*}$ \\
\hline \multicolumn{3}{|l|}{ Gender } \\
\hline Male & 135,000 & 66 \\
\hline Female & 68,900 & 34 \\
\hline \multicolumn{3}{|l|}{ Age } \\
\hline Teens & $1,300 *$ & $1 *$ \\
\hline $20 s$ & 45,000 & 22 \\
\hline $30 s$ & 91,400 & 45 \\
\hline $40 s$ & 55,200 & 27 \\
\hline $50 s$ & $3,000 *$ & $1 *$ \\
\hline $60 \mathrm{~s}$ & $1,400^{*}$ & $1 *$ \\
\hline No information & $6,600 *$ & $3 *$ \\
\hline
\end{tabular}

Note: All estimates are rounded to the nearest 100. Percents may not sum to 100 because of rounding.

* Estimate is based on too few sample cases to be reliable.

Indicators of serious episodes. Table 7 shows that the use of threats, physical force, or weapons was relatively uncommon in family abductions. Seventeen percent of family abducted children were moved out of State with intent to make recovery difficult. Forty-four percent were concealed from the aggrieved caretaker. The most common serious elements were attempts to prevent contact (76 percent) and intent to affect custodial privileges permanently ( 82 percent). 


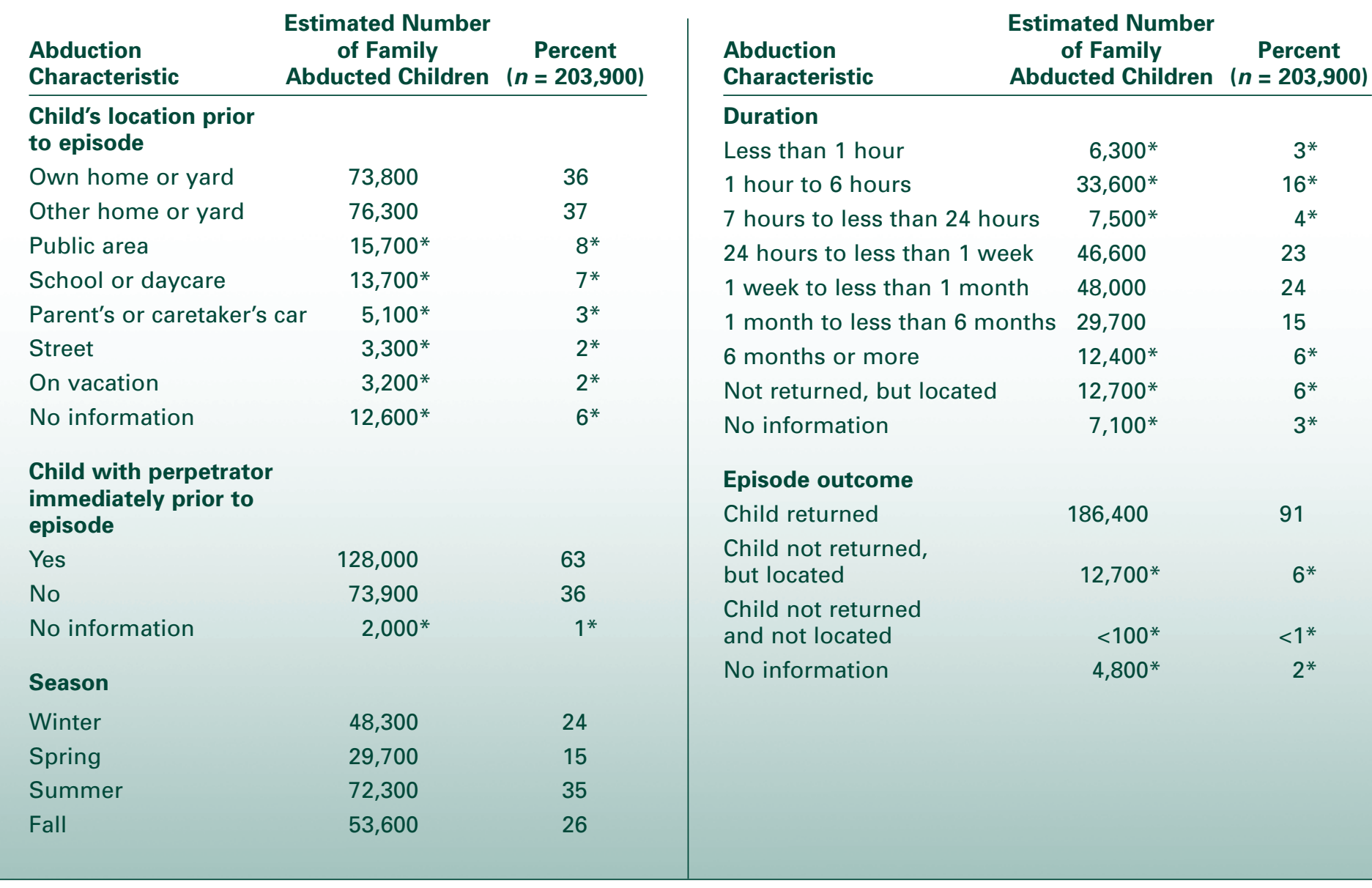

Note: All estimates are rounded to the nearest 100. Percents may not sum to 100 because of rounding.

* Estimate is based on too few sample cases to be reliable.

\section{Police Contact}

As shown in table 8, aggrieved caretakers contacted the police regarding 60 percent of the family abducted children. However, not all of these contacts were for the purpose of locating the child. Fifty percent of the contacts were to recover the child from a known location; 42 percent were to locate the child.

Caretakers did not contact the police regarding 40 percent of the family abducted children, citing a variety of reasons. In some cases, they resolved the episode on their own (23 percent) or with a lawyer ( 6 percent). Some believed that police assistance was not necessary because they knew the child's location (10 percent) or knew that the child would not be harmed (6 percent). Some caretakers feared the child would be harmed if they contacted the police 16 percent). Others did not think the police could help (15 percent), were dissatisfied with police response to a previous contact ( 8 percent), or had been advised by others not to contact the police ( 3 percent).

\section{Historical Trends}

A special analysis of NISMART-1 and NISMART-2 data was conducted to identify historical trends in family abduction. ${ }^{4}$ The analysis suggests that, between 1988 and 1999, the incidence rate of children who were victims of serious family abductions did not change, but there may have been a decline in the rate for children who were victims of less serious episodes involving various forms of custodial interference. Details of this 
Table 7: Indicators of More Serious Family Abductions

\begin{tabular}{|c|c|c|}
\hline $\begin{array}{l}\text { Abduction } \\
\text { Characteristic }\end{array}$ & $\begin{array}{l}\text { Estimated } \\
\text { Number } \\
\text { of Family } \\
\text { Abducted } \\
\text { Children }\end{array}$ & $\begin{array}{c}\text { Percent } \\
(n=203,900)\end{array}$ \\
\hline \multicolumn{3}{|l|}{ Use of threat } \\
\hline Yes & $9,000 *$ & $4^{*}$ \\
\hline No & 183,900 & 90 \\
\hline No information & $11,000^{*}$ & $5^{*}$ \\
\hline \multicolumn{3}{|l|}{ Use of force } \\
\hline Yes & $15,000^{*}$ & $7^{*}$ \\
\hline No & 177,900 & 87 \\
\hline No information & $11,000^{*}$ & $5^{*}$ \\
\hline \multicolumn{3}{|l|}{ Use of weapon } \\
\hline Yes & $2,700^{*}$ & $1^{*}$ \\
\hline No & 190,200 & 93 \\
\hline No information & $11,000^{*}$ & $5^{*}$ \\
\hline \multicolumn{3}{|c|}{$\begin{array}{l}\text { Child taken out of State } \\
\text { with intent to make } \\
\text { recovery more difficult }\end{array}$} \\
\hline Yes & 35,200 & 17 \\
\hline No & 168,700 & 83 \\
\hline \multicolumn{3}{|l|}{ Child concealed } \\
\hline Yes & 90,600 & 44 \\
\hline No & 113,300 & 56 \\
\hline \multicolumn{3}{|c|}{ Intent to prevent contact } \\
\hline Yes & 153,900 & 76 \\
\hline No & 46,900 & 23 \\
\hline No information & $3,000 *$ & $1^{*}$ \\
\hline \multicolumn{3}{|c|}{$\begin{array}{l}\text { Intent to affect } \\
\text { custody permanently }\end{array}$} \\
\hline Yes & 166,600 & 82 \\
\hline No & 37,300 & 18 \\
\hline
\end{tabular}

Note: All estimates are rounded to the nearest 100 . Percents may not sum to 100 because of rounding.

* Estimate is based on too few sample cases to be reliable.
Table 8: Police Contact for Family Abductions

\begin{tabular}{lcr} 
& $\begin{array}{c}\text { Estimated } \\
\text { Number } \\
\text { of Family } \\
\text { Abducted } \\
\text { Children }\end{array}$ & \\
& Percent \\
\hline Police contact & 121,800 & 60 \\
Yes & 82,100 & 40 \\
No & 203,900 & 100 \\
Total & &
\end{tabular}

Reason police were contacted

Recover child from known location

61,100 50

Locate missing child

50,800

Other reason

$6,900^{*}$

$6^{*}$

No information

$3,000^{*}$

$2^{*}$

Total

121,800

100

\section{Reason police were} not contacted

Resolved problem alone or with family

$19,100^{*} \quad 23^{*}$

Did not think police could help

$12,200^{*} \quad 15^{*}$

Knew child's location

$7,900^{*}$ $10^{*}$

Dissatisfied with prior police contact

$6,300^{*}$

$8^{*}$

Afraid that child would be harmed

$5,300^{*}$

$6^{*}$

Handled problem with lawyer

$4,900^{*}$

$$
6^{*}
$$

Knew that child would not be harmed

$4,500^{*}$

Advised by others not to contact police

$2,400^{*}$

$3,800^{*}$

$15,700^{*}$

82,100

$$
6^{*}
$$

No information$$
3^{*}
$$

Total

Note: All estimates are rounded to the nearest 100. Percents may not sum to 100 because of rounding. 
analysis will be presented in OJJDP's forthcoming Bulletin, Historical Change in the Incidence of Missing, Abducted, Runaway, and Thrownaway Children, 1988-1999.

\section{Conclusions and Policy Implications}

Family abductions constitute an important peril in the lives of children, particularly children living in households without one of their biological parents. The estimated 203,900 children who were victims of a family abduction in 1999 represent a large group of children caught up in divisive and potentially disturbing family dynamics.

\section{Need for Services That Address} Underlying Conflicts

Fifty-seven percent of the children who were abducted by a family member were caretaker missing (in the sense that their caretaker did not know where they were, became alarmed, and tried to locate them). Family abducted children constituted only 9 percent of all children classified as caretaker missing and only 7 percent of all children reported missing. In considering these statistics, however, it is important to remember that the potential for harm to family abducted children exists whether or not they are classified as missing. Family abduction is not just a problem of missing children.

In addition to locating and returning family abducted children, agencies seeking to help these children must address the conflicts that produce and prolong the abduction of children by family members. The fact that fully 40 percent of family abductions were not reported to the police underscores the importance of agencies that can provide a response to threatened and actual family abductions over and above the important location and recovery function performed by law enforcement.

\section{Reality vs. Stereotype}

Although the family abductions described in this study typically had certain disturbing elements such as attempts to prevent contact or alter custodial arrangements permanently, they did not generally involve the most serious sorts of features associated with the types of family abductions likely to be reported in the news. Actual concealment of the child occurred in a minority of episodes. Use of force, threats to harm the child, and flight from the State were uncommon. In contrast to the image created by the word "abduction," most of the children abducted by a family member were already in the lawful custody of the perpetrator when the episode started. In addition, nearly half of the family abducted children were returned in 1 week or less, and the majority were returned within 1 month.

\section{Limitations of the Findings}

The fact that family abductions in this study tended to resolve themselves in time should not lead one to assume that most family abductions are relatively benign and can be resolved without the intervention of authorities. The researchers in this study were not in a position to provide a full assessment of the types of harm that family abductions inflicted on children or the extent to which intervention by outside authorities facilitated the resolution of family abductions. ${ }^{5}$

\section{Focus on Younger Children}

This study's finding that younger children are the ones at greater risk of family abduction parallels findings from previous NISMART studies and other studies as well. Family abduction is one of the few victimization perils that younger children experience to a greater extent than older children. Thus, prevention efforts should focus on younger children, especially those who do not live with both biological parents. Programs that specifically promote child well-being and those that address child safety issues generally may be appropriate forums in which to raise awareness about family abduction.

The estimate of the number of family abducted children known to police from this NISMART-2 study, approximately 121,800 in 1999, contrasts with a 1992 estimate of 30,500 family abductions known to police based on a survey of law enforcement agencies (Grasso et al., 2001). The discrepancy could reflect a change in helpseeking patterns during the 1990s in the wake of family abductions. It may be that victims of family abduction in NISMART-2 overstated to interviewers their propensity to contact police. But more likely, it reflects the fact that police do not keep full records of all the individuals who contact them about family abductions and may not categorize the episodes as such in their databases. 


\section{An Area in Need of Further Attention}

Despite close to 20 years of organized concern about missing children, and despite the creation of missing child prevention and intervention programs, the family abduction problem remains one area where efforts may be the least developed. Knowledge about the number of children who experience family abductions should spur efforts to prevent the occurrence of family abductions and help children and their aggrieved caretakers recover from the effects of these abductions when they occur.

\section{Endnotes}

1. One obvious limitation of the Household Surveys is that they may have undercounted children who experienced episodes but were living in households without telephones or were not living in households during the study period, including street children and homeless families. Although these are not large populations in comparison to the overall child population, they may be at risk for episodes. Other methodological factors, such as a preponderance of female caretaker interviewees and a greater likelihood of getting information about children in their primary residential household, may have resulted in some undercounting of family abductions perpetrated by females and caretakers with primary custody.

2. The absence of any stepmother perpetrators does not mean that there are no such abductions, only that they were too infrequent to have been detected in this study.

3. The absence of any family abducted children who were not located does not mean that these children do not exist, only that they were too infrequent to have been detected in this study.

4. Because of important differences in both definitions and methodology, the NISMART-1 and NISMART-2 data and findings should not be compared directly. In drawing comparisons to identify trends, researchers used the closest possible approximations of NISMART-1 methodology and definitions.
5. NISMART-1 found that family abduction can result in psychological harm to the child (Finkelhor, Hotaling, and Sedlak, 1990). Other studies (e.g., Grasso et al., 2001) have also found that family abduction cases may not receive the attention needed from the criminal justice system and that international family abductions in particular may be more difficult to resolve and often involve serious characteristics (e.g., concealment, threats).

\section{References}

Finkelhor, D., Hotaling, G., and Sedlak, A. 1990. Missing, Abducted, Runaway, and Thrownaway Children in America. First Report: Numbers and Characteristics National Incidence Studies. Washington, DC: U.S. Department of Justice, Office of Justice Programs, Office of Juvenile Justice and Delinquency Prevention.

Grasso, K.L., Sedlak, A.J., Chiancone, J.L., Gragg, F., Schultz, D., and Ryan, J.F. 2001. The Criminal Justice System's Response to Parental Abduction. Bulletin. Washington, DC: U.S. Department of Justice, Office of Justice Programs, Office of Juvenile Justice and Delinquency Prevention.

U.S. Census Bureau. 2000. Monthly Postcensal Resident Population, by Single Year of Age, Sex, Race, and Hispanic Origin (e9899rmp.txt, e9999rmp.txt, and e9900rmp. txt). Web site: eire.census.gov/popest/archives/national/ nat_90s_detail/nat_90s_1.php.

This Bulletin was prepared under grant number 95-MC-CX-K004 from the Office of Juvenile Justice and Delinquency Prevention, U.S. Department of Justice, to Temple University.

The Office of Juvenile Justice and Delinquency Prevention is a component of the Office of Justice Programs, which also includes the Bureau of Justice Assistance, the Bureau of Justice Statistics, the National Institute of Justice, and the Office for Victims of Crime. 


\section{For Further Information}

NISMART Questions and Answers, a fact sheet, offers a straightforward introduction to NISMART-2. It answers anticipated questions-such as What is NISMART? Have abductions by strangers declined or increased? and Why can't I compare NISMART-1 statistics with NISMART-2 statistics?-to help explain NISMART's purpose, methodology, and findings.

The first Bulletin in the NISMART series, National Estimates of Missing Children: An Overview, describes the NISMART-2 component studies and estimating methodology, defines the types of episodes studiednonfamily abduction (including stereotypical kidnapping); family abduction; runaway/thrownaway; missing involuntary, lost, or injured; and missing benign explanation-and summarizes NISMART-2 estimates of missing children.

AII NISMART-related publications are available at OJJDP's Web site, ojjdp.ncjrs.org.

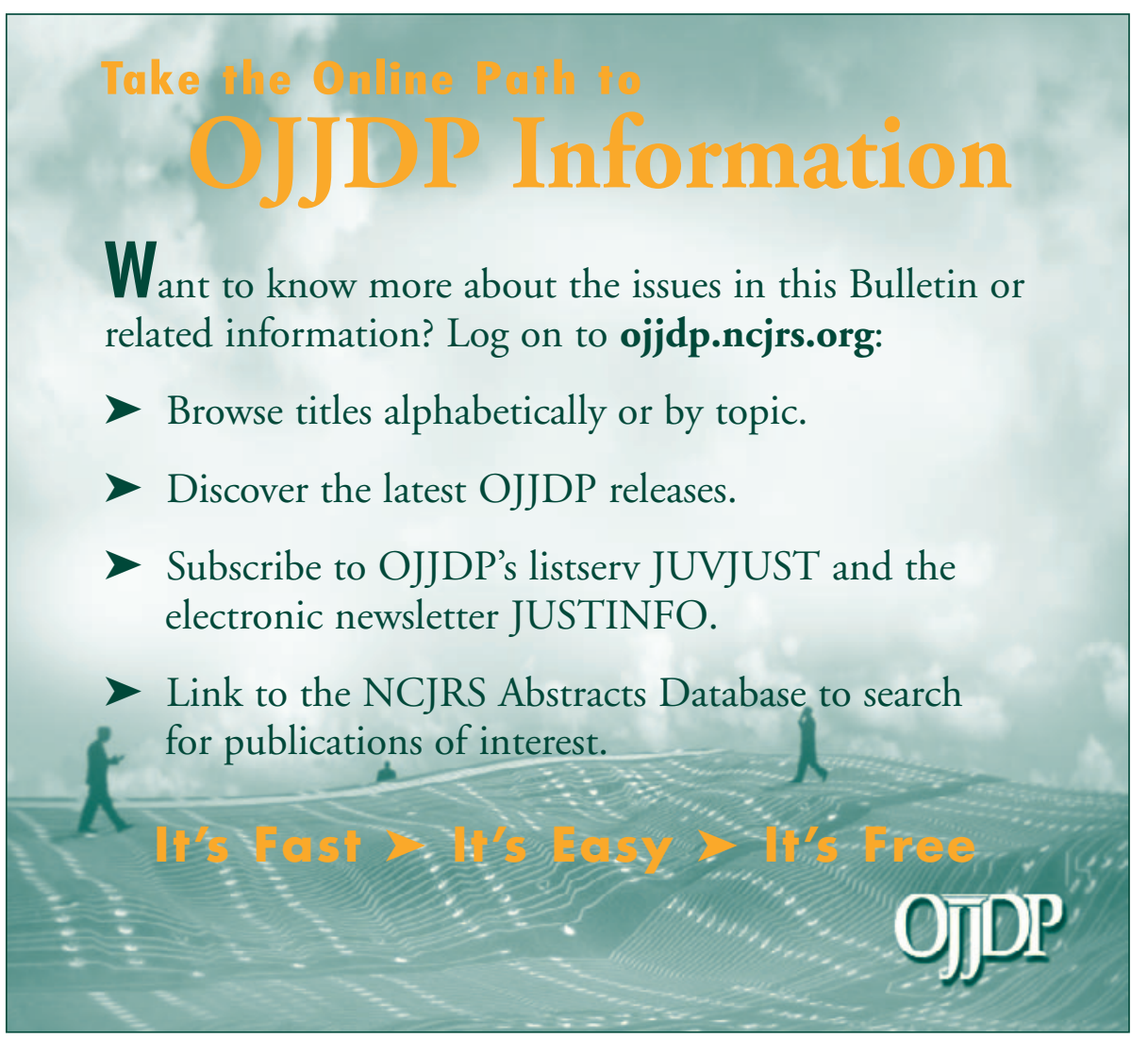

\section{Acknowledgments}

Heather Hammer, Ph.D., is a Senior Study Director at the Temple University Institute for Survey Research, Philadelphia, PA, and Principal Investigator of NISMART-2. David Finkelhor, Ph.D., is Professor of Sociology and Director, Crimes against Children Research Center, University of New Hampshire, and Advisor to NISMART-2. Andrea J. Sedlak, Ph.D., is Associate Director of Human Services Research at Westat, Inc.; Project Director of the NISMART-2 Unified Estimate, Juvenile Facilities Study, and Law Enforcement Study; and Advisor to the NISMART-2 Household Survey.

Other contributors include Louise Hanson, M.A.S., Senior Study Director at the Temple University Institute for Survey Research and Director of Data Collection for the NISMART-2 Household Surveys; Michael K. Barr, M.A., Associate Study Director at the Temple University Institute for Survey Research; Dana J. Schultz, M.P.P., Policy Analyst at Westat, Inc., Operations Manager of the Juvenile Facilities Study and Law Enforcement Study, and Analyst for the Unified Estimate; Richard Ormrod, Ph.D., Research Professor of Geography at the University of New Hampshire Crimes against Children Research Center; G. Hussain Choudhry, Ph.D., Senior Statistician at Westat, Inc.; Svetlana Ryaboy, Statistician at Westat, Inc.; Monica Basena, Analyst at Westat, Inc.; and Ying Long, Programmer at Westat, Inc.

The authors extend their appreciation to Barbara Allen-Hagen, Senior Social Analyst at OJJDP and NISMART-2 Program Manager, for her support and guidance in every phase of this project. The authors also thank the many individuals who responded to the NISMART-2 surveys for their cooperation and candor. 
U.S. Department of Justice

PRESORTED STANDARD

Office of Justice Programs

POSTAGE \& FEES PAID DOJ/OJJDP

Office of Juvenile Justice and Delinquency Prevention PERMIT NO. G-91

Washington, DC 20531

Official Business

Penalty for Private Use $\$ 300$ 